\title{
Aseksualitas dalam Drama TV Sherlock di Televisi BBC One
}

\author{
Muslikhin $^{1}$ dan Elsa Tesalonika Lalong ${ }^{2}$ \\ ${ }^{1.2}$ Fakultas Ekonomi dan Komunikasi \\ Universitas Bina Nusantara \\ J1. K. H. Syahdan No. 9, Palmerah, Jakarta Barat 11480 \\ Imdmuslihin@gmail.com, ${ }^{2}$ elsatesalonika@yahoo.com
}

\begin{abstract}
Sherlock is an adaptation of the Sherlock Holmes story in the form of a television drama on BBC One. Sherlock uses the 21st-century setting, as a substitute for Victorian (1830-1901) like the original story of Sherlock Holmes. The Sherlock Holmes character, especially his sexual orientation raises debates among critics and the fans of Sherlock story. This happens because the writer does not clearly and firmly provide an overview of the sexual orientation of Sherlock Holmes. This study aims to determine the signs that represent the asexuality of Sherlock Holmes figures by analyzing the relationship of Sherlock with several other figures and Sherlock as a person who shows the characteristics of asexuality. The research method used is Semiotics by Ferdinand de Saussure. The basic analysis of asexuality used is the ten characteristics of the asexuality by Decker. The conclusion of this study is Sherlock Holmes is an asexual because it meets 8 out of 10 asexual traits according to Decker.
\end{abstract}

Keywords: Asexuality, Saussure, Semiotics, Sexual orientation, Sherlock Holmes

\begin{abstract}
Abstrak
Sherlock adalah sebuah adaptasi dari cerita Sherlock Holmes dalam bentuk drama televisi di BBC One. Sherlock menggunakan latar abad ke-21, sebagai pengganti jaman Victoria (1830-1901) seperti cerita asli Sherlock Holmes. Karakter tokoh Sherlock Holmes, terutama orientasi seksualnya menimbulkan perdebatan di kalangan kritisi dan penggemar cerita Sherlock. Hal ini terjadi karena penulis cerita tidak secara jelas dan tegas memberikan gambaran tentang orientasi seksual dari Sherlock Holmes. Penelitian ini bertujuan untuk mengetahui tanda-tanda yang merepresentasikan aseksualitas pada tokoh Sherlock Holmes sebagai pribadi yang menunjukkan ciri-ciri aseksualitas. Metode penelitian yang digunakan adalah Semiotika Ferdinand de Saussure. Dasar analisis aseksualitas yang digunakan adalah 10 ciri-ciri aseksualitas dari Decker. Penelitian ini menyimpulkan Sherlock Holmes adalah seorang aseksual karena memenuhi 8 dari 10 ciri-ciri aseksual menurut Decker.
\end{abstract}

Kata kunci : Aseksualitas, Orientasi seksual, Saussure, Semiotika, Sherlock Holmes

Copyright $@ 2018$ Ikatan Sarjana Komunikasi Indonesia. All rights reserved

\section{PENDAHULUAN}

Tokoh Sherlock Holmes termasuk salah satu tokoh yang paling populer dan banyak diperankan dalam film dan serial televisi. Pada 2012, Guinness World Record memberikan penghargaan kepada Sherlock Holmes sebagai most portrayed literary human character in film and TV atau karakter sastra yang paling banyak diperankan dalam film dan serial TV. Sejak 1887, Sherlock Holmes muncul di layar televisi dan film sebanyak 254 kali dan dimainkan 75 aktor berbeda. Salah satunya adalah Sherlock yang diproduksi $B B C$ dan telah tayang di TV berlangganan AXN Asia.

Sherlock produksi BBC One tersebut berbeda dibandingkan dengan novel dan cerpennya. Perbedaan terletak pada latar cerita. Sherlock produksi BBC One memiliki latar abad ke-21, sedangkan novel dan cerpennya berlatar jaman Victoria (1830-1901). Sejak diproduksi pada 2010 sampai 2017, Sherlock memiliki 13 episode dan 1 episode mini dalam 4 series serta 1 episode Christmas special.

Salah satu yang menjadi perdebatan dari cerita Sherlock Holmes adalah orientasi seksual tokoh utamanya, Sherlock Holmes. Penyebabnya karena Arthur Conan Doyle sebagai penulis cerita Sherlock 
Holmes tidak pernah menuliskan dalam karya-karyanya bahwa Sherlock Holmes pernah menikah, memiliki anak, atau bahkan memiliki pacar. Hal ini yang kemudian menjadi rumor kalau Sherlock dan John Watson partner kerja dan sahabat Sherlock - adalah pasangan homoseksual. Beberapa film adaptasi tokoh Sherlock Holmes pun membuat lelucon homoseksualitas, seperti film The Private Life of Sherlock Holmes, yang di dalamnya ada adegan Sherlock berpura-pura berpacaran dengan John untuk menolak ajakan menikah Madam Petrova, seorang balerina ternama di jaman Victoria.

Di era Victoria, patriarki, sistem di masyarakat dan pemerintahan di mana pria memiliki kekuatan dan wanita menjadi pengecualian, masih menjadi pegangan hidup. Wanita dianggap sebagai jenis kelamin yang lemah secara fisik dan intelektual. Pria mendapatkan hak mengambil keputusan politik, legal, dan ekonomi. Dalam kehidupan pribadi, wanita juga dianggap sebagai "subyek" bagi ayah, suami, saudara laki-laki, bahkan anak laki-laki.

Hukum dan norma tersebut menyebabkan masyarakat mengharapkan pria untuk menikah supaya bisa mendapatkan pelayanan rumah tangga dari wanita. Jika seorang pria tidak menikah, masyarakat akan menganggapnya tidak tertarik terhadap wanita atau homoseksual. Hubungan seksual antar laki-laki adalah perbuatan yang melanggar hukum Britania Raya (gross indecency) dan bisa dijatuhi hukuman seperti dua tahun kerja keras (hard labour) yang dijatuhkan pada Oscar Wilde pada 1895. Hukuman mati bagi pelaku sodomi (memasukkan penis ke dalam lubang dubur; anal sex; buggery) baru dihapuskan tahun 1861.

Tokoh Sherlock sering dianggap homoseksual karena ia tidak pernah terlihat memiliki pacar atau istri, serta tinggal dalam satu flat bersama John. Namun diketahui John pindah tempat tinggal setelah menikah, memiliki anak, dan Sherlock tetap melajang. John mengetahui Sherlock tetap melajang karena memang tidak tertarik dengan hubungan seksual.

Mark Gatiss sebagai penulis naskah Sherlock pun mengakui adanya lelucon homoseksualitas antar Sherlock dan John dalam Sherlock (Tribe, 2014). Sedangkan Steven Moffat sebagai produser Sherlock juga memberikan pernyataan dalam wawancara Entertainment Weekly bahwa Sherlock bukan seorang heteroseksual maupun homoseksual. Adanya pernyataan Gatiss dan Moffat menyebabkan Sherlock Holmes dalam Sherlock memiliki kemungkinan sebagai seorang aseksual.

Julie Sondra Decker ( 2015) menyatakan, "Asexuality is usually defined as the experience of not being sexually attracted to others. Less commonly, it is defined as not valuing sex or sexual attraction enough to pursue it". Aseksualitas adalah ketika seseorang tidak memiliki rasa ketertarikan seksual terhadap siapa pun, pria maupun wanita.

Orientasi seksual dalam pandangan Decker (2015) bukan merupakan pilihan atau gaya hidup seperti pantangan hubungan seksual (celibacy) dan menahan diri dari hubungan seksual sebelum menikah (chastity). Manusia memiliki dua orientasi, yaitu orientasi seksual (heteroseksual, homoseksual, biseksual, dan aseksual) dan orientasi romantis (heteroromantis, homoromantis, biromantis, dan aromantis). Setiap manusia memiliki kombinasi kedua orientasi tersebut, karena keinginan seksual (desire) dan cinta romantis (romatic love) berfungsi independen dalam otak.

Decker (2015) menyatakan, ada 10 ciri-ciri aseksualitas. Pertama, sehat secara fisik dan mental, serta tidak berada dalam pengaruh obat. Kedua, tidak mengalamai cacat. Ciri kedua ini merupakan tindak lanjut dari ciri pertama, yaitu seorang harus tidak memiliki cacat baik fisik maupun mental. Ketiga, tidak pernah mengalami siksaan atau perlakuan kejam secara seksual. Keempat, ekstrover dan/atau berkompetensi sosial. Kelima, seorang cisgender (bukan transgender, non-binary, gender fluid, agender, genderqueer, neutrois, bigender, third gender, atau gender questioning). Keenam, mendukung praktik hubungan seksual orang lain (walaupun berbeda dengan praktik yang dilakukan diri sendiri). Ketujuh, tidak memiliki libido. Kedelapan, menarik secara fisik. Kesembilan, tidak tertarik pada hubungan romantis (atau terkadang tertarik dengan hubungan hetero). Kesepuluh, berumur di antara dua puluh hingga empat puluh tahun.

Gender itu berbeda dengan jenis kelamin (sex). Gender (maskulin, feminin, umum, dan netral) ditentukan berdasarkan pemahaman sosial dan budaya, sedangkan jenis kelamin (pria dan wanita atau jantan dan betina) ditentukan berdasarkan fungsi organ reproduksi secara biologis 
Penelitian Anthony Bogaert (2004) tentang persentase jumlah aseksual di Britania Raya (British residents) menggambarkan sebanyak $1 \%$ orang di Britania Raya adalah aseksual. Jumlah wanita aseksual lebih banyak daripada pria.

Bogaert kemudian melanjutkan penelitiannya dan mempublikasikan buku yang menjadi buku pertama membahas aseksual dari sisi psikologi dan biologi berjudul Understanding Asexuality (2015). Bogaert menyatakan bahwa aseksualitas bukan gangguan (disorder), seperti Hypoactive Sexual Desire Disorder yang terjadi jika seseorang pernah merasakan keinginan seksual (sexual desire) namun keinginan tersebut menurun atau hilang. Seorang aseksual tidak pernah merasakan keinginan seksual dalam hidupnya. Aseksual juga bukan abnormalitas, hanya karena dianggap melawan hukum alam bahwa 'seks adalah proses natural' yang bertujuan untuk bereproduksi.

Kata 'aseksualitas' masih kurang populer di Indonesia. Belum ditemukan karakter fiksi dalam novel/film/drama televisi atau tokoh masyarakat asal Indonesia yang mampu menunjukkan aseksualitas.

Penelitian ini berfokus pada tanda-tanda yang merepresentasikan aseksualitas seperti diuraikan Decker ( 2015) pada tokoh Sherlock dengan meneliti hubungannya dengan tokoh lainnya serta tokoh Sherlock sebagai pribadi yang menunjukkan aseksualitas, melalui gambar (scene) dan audio (dialog) dalam drama televisi Sherlock. Ada lima episode yang dipilih. Sherlock merupakan drama yang fokus kepada kasus kriminal, oleh karena itu satu episode saja tidak akan cukup untuk mencari tanda-tanda yang mampu merepresentasikan aseksualitas pada tokoh Sherlock Holmes.

\section{METODE PENELITIAN}

Penelitian menggunakan metode semiotika Ferdinand de Saussure. Dalam pandangan Saussure, bahasa adalah sebuah tanda, yang terdiri dari signifier (penanda) dan signified (petanda) (Nawiroh, 2014). Signifier adalah coretan yang mempunyai arti atau makna. Signified merupakan gambaran mental atau konsep dari signifier (Sobur, 2009). Semiotika Saussure dipilih sebagai metode analisis karena paling sesuai dengan tujuan penelitian yaitu menjelaskan tanda-tanda aseksualitas dari dalam tokoh Sherlock Holmes.

Tanda-tanda yang mampu merepresentasikan aseksualitas tokoh Sherlock Holmes dianalisis lewat hubungannya dengan tokoh lainnya yaitu John Watson (dan Mary Watson), Molly Hooper, Irene Adler, dan Janine Hawkins, serta tokoh Sherlock Holmes sebagai pribadi yang menunjukkan aseksualitas, melalui gambar (scene) dan audio (dialog) dalam drama televisi Sherlock.

\section{HASIL PENELITIAN}

Adapun episode yang dianalisis adalah sebagai berikut:

A Scandal in Belgravia banyak mengambil elemen dalam karya asli Doyle berjudul A Scandal in Bohemia. Keduanya menampilkan tokoh Irene Adler, tokoh wanita satu-satunya yang memiliki kedekatan khusus dengan Sherlock Holmes dalam karya asli Doyle. Perbedaannya, Irene dalam A Scandal in Bohemia bekerja sebagai penyanyi opera, sedangkan Irene dalam A Scandal in Belgravia menjadikan dominatrix sebagai pekerjaan. Dominatrix adalah wanita yang berperan sebagai seorang sadis dalam aktivitas seksual sadomasokisme. Sadomasokisme adalah hubungan seks dengan praktik kekerasan.

The Empty Hearse menjadi episode pertama kalinya Sherlock bertemu dengan pacar (kemudian menjadi istri) John, yaitu Mary Morstan (kemudian Mary Watson). John adalah satu-satunya tokoh yang menjadi sahabat Sherlock dan pernah menikah sebanyak dua kali dalam karya asli Doyle, namun kematian Mary dan nama istri kedua John tidak pernah dituliskan. Mary yang ada di dalam karya asli Doyle pertama kali muncul di novel The Sign of Four.

The Sign of Three menjadi episode khusus pernikahan John dan Mary. Sherlock membantu perencanaan, memberikan pidato pernikahan, dan orang pertama yang memberikan deduksi bahwa Mary sedang hamil dalam pesta pernikahan. John dalam Sherlock hanya menikah satu kali.

His Last Vow menampilkan tokoh Janine Hawkins sebagai pacar dan calon tunangan Sherlock. Janine merupakan tokoh pertama yang disebutkan sebagai pacar saat John bertanya pada Sherlock tentang status 
percintaannya. Mereka pertama kali bertemu di pernikahan dalam episode The Sign of Three dan Janine merupakan sahabat Mary. Tokoh Janine tidak ada dalam karya asli Doyle.

The Final Problem menampilkan kisah tentang masa kecil dan keluarga Sherlock Holmes. The Final Problem menampilkan tokoh baru yaitu Eurus Holmes yang merupakan anak ketiga keluarga Holmes. Dalam karya asli Doyle, keluarga Holmes hanya memiliki dua anak yaitu Mycroft dan Sherlock.

John selalu ada dalam setiap episode Sherlock. Dalam kelima episode tersebut, juga terdapat tokoh Molly Hooper. Molly tidak ada dalam karya asli Doyle, namun Molly merupakan tokoh wanita yang juga memiliki kedekatan khusus dengan Sherlock.

Data dianalisis melalui identifikasi teks yang heterogen (keanekaragaman) diproses agar dapat diketahui strukturnya. Kumpulan teks tersebut disebut korpus. Kemudian analisis korpus-korpus sesuai dengan model semiotika yang dipilih. Terakhir, pemaknaan oleh peneliti disesuaikan dengan teori yang digunakan, menghubungkan dengan tanda lain, dan lain-lain (Nawiroh, 2014).

Uji keabsahan data menggunakan uji kredibilitas dengan cara triangulasi sumber dan formula tiga dan sembilan uji keabsahan data dalam penelitian semiotika model Andrik Purwasito (2007). Formula tiga adalah menguji pesan secara kontekstual yaitu pengujian konteks fisik setempat dan konteks waktu di mana tanda itu digunakan. Sedangkan formula sembilan adalah menguji pesan secara subyektif yaitu melakukan tafsir intuitif oleh peneliti sendiri dengan mendasarkan pada pengalaman intelektual, keyakinan dan pengembaraan ilmiahnya.

\section{PEMBAHASAN}

Decker (2015) seperti diuraikan sebelumnya, menyatakan ada 10 ciri-ciri aseksualitas. Berikut hasil analisis dan pembahasan ke 10 ciri-ciri aseksualitas dari tokoh Sherlock Holmes yang muncul dalam serial Sherlock produksi BBC.

\section{Sehat secara fisik dan mental, serta tidak berada dalam pengaruh obat}

Ciri ini menjelaskan, ketika seseorang menggunakan obat-obatan seperti narkoba dan pil birth control masuk kategori tidak sehat secara fisik dan mental. Penggunaan pil birth control bisa menyebabkan efek samping berupa menurunnya libido/nafsu birahi (sex drive) karena beberapa birth control mencegah ovulasi (terlepasnya sel telur dari indung telur). Decker menyatakan, seorang aseksualitas tidak memiliki libido. Tetapi tidak memiliki libido tersebut bukan disebabkan oleh penggunaan obat-obat, namun secara naluri atau alami.

Penelitian terhadap serial Sherlock yang diproduksi BBC menemukan bukti kalau Sherlock Holmes pernah menggunakan plester nicotine (nicotine patch) sebagai pengganti rokok. Selain itu Sherlock juga pernah menggunakan narkoba, walaupun bukan dikonsumsi untuk dirinya, namun untuk menjebak musuhnya, Charles Augustus Magnussen dan Culverton Smith. Dengan demikian, secara fisik dan mental, sulit untuk mengatakan Sherlock Holmes adalah sehat. Itu artinya Sherlock tidak memenuhi kriteria pertama sebagai seorang aseksual

\section{Tidak bercacat}

Kecacatan atau disabilitas tidak langsung membuat libido menurun, namun kecacatan mampu menjadi faktor menurunnya libido. Contohnya seseorang yang disabilitas pada tulang belakang akan mampu mengubah aktivitas seksualnya. 


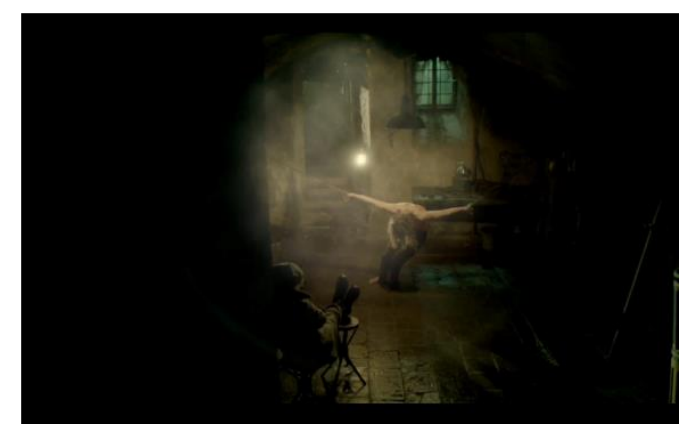

Gambar 1 Sherlock dirantai dan dipukuli

Dalam salah satu adegan seperti dalam gambar 1, Sherlock berlari-lari di tengah hutan di Serbia untuk melacak musuhnya yaitu Jim Moriarty (penanda). Sherlock kemudian tertangkap oleh tentara Serbia. Setelah tertangkap, ia dirantai dan dipukuli oleh tentara Serbia karena tidak memberitahukan identitasnya. Adegan tersebut menunjukkan bahwa Sherlock memiliki badan yang tidak bercacat. Jika bercacat, Sherlock akan kesulitan melakukan pelacakan Jim melalui kegiatan fisik (petanda). Dengan demikian, Sherlock memiliki ciri aseksualitas, yaitu tidak bercacat.

\section{Tidak pernah mengalami siksaan atau perlakuan kejam [secara seksual]}

Adapun yang membedakan aseksualitas dan Hypoactive Sexual Desire Disorder atau HSDD adalah $H S D D$ memiliki sebuah alasan yang menyebabkan seseorang memiliki ketertarikan seksual yang rendah. Contohnya trauma seksual (pemerkosaan, pedofilia, dan pelecehan).

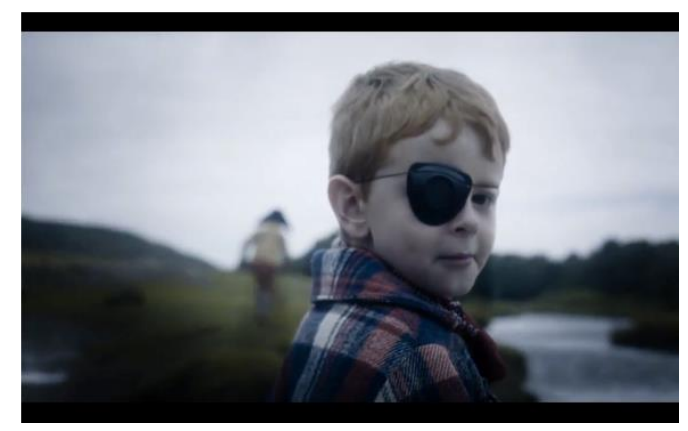

Gambar 2 Victor Trevor

Dalam salah satu adegan, seperti dalam gambar 2, Sherlock pernah mengalami trauma masa kecil di usia 6 tahun ketika Eurus (adik Sherlock; 1 tahun lebih muda dari Sherlock; 8 tahun lebih muda dari Mycroft) membunuh Victor Trevor (sahabat Sherlock). Jenazah Victor tidak pernah ditemukan dan hanya dinyatakan hilang. Eurus dipenjara di sebuah institusi kejiwaan bernama Sherrinford di sebuah pulau terpencil oleh pamannya, Uncle Rudy. Ketika Mycroft dewasa, ia membantu Uncle Rudy memalsukan kematian Eurus. Uncle Rudy merekayasa pikiran Sherlock dengan mengganti figur Victor dengan figur anjing, Redbeard. Trauma yang pernah dialami Sherlock bukan perlakuan kejam secara seksual. Trauma yang dialami Sherlock berupa mengetahui bahwa sahabatnya, Victor Trevor hilang dan tidak ditemukan. Dengan kondisi demikian, Shrerlock masuk kreteria memiliki orientasi aseksualitas, yaitu tidak pernah mengalami sisksaan atau perlakukan kejam secara seksual.

\section{Ekstrover dan/atau berkompetensi sosial}

Aseksualitas berbeda dengan Antisocial Personality Disorder (ASPD) atau sociopathy yaitu kondisi mental seseorang yang tidak mampu membedakan sesuatu sebagai baik atau buruk, serta mengacuhkan hak dan perasaan orang lain. 
Penelitian tidak dapat membuktikan ciri keempat karena Sherlock memperkecil lingkup pertemanannya, seperti hanya mengundang beberapa orang (John, Mary, Mrs. Hudson, Lestrade, dan Molly) ke dalam flat dalam waktu yang bersamaan (S03E02, 01.22.07). Sherlock diidentikan sebagai orang paling tidak sosial. Sherlock juga menghindari difoto oleh media dan mengatakan pada Inspektur Lestrade, "I am private detective. The last thing I need is a public image" (S02E01, 00.07.42-00.07.45). Bahkan ketika John menyebut Major Sholto sebagai 'the most unsociable man', ia merasa cemburu (platonic love) karena merasa dirinya lebih pantas disebut seperti itu. Tanda-tanda yang mucul dalam Sherlock menunjukkan kalau Sherlock bukan seorang ekstrover, tetapi introver serta kurang memiliki kompetensi sosial.

\section{Seorang cisgender (bukan transgender, non-binary, gender fluid, agender, genderqueer, neutrois, bigender, third gender, atau gender questioning)}

Cisgender terkait dengan identitas personal dan gender seseorang yang sesuai dengan jenis kelamin sejak lahir. Contohnya terlahir dengan alat kelamin penis dan cenderung memiliki gender maskulin. Berikut adalah penjelasan beberapa istilah dalam ciri-ciri tersebut.

Transgender adalah antonim dari cisgender. Contohnya terlahir dengan alat kelamin vagina namun cenderung memiliki gender maskulin. Transgender tidak berarti harus melakukan operasi pergantian kelamin (sex reassignment surgery), contohnya seseorang yang merasa sebagai wanita dalam tubuh pria mengidentifikasi diri sebagai transgender namun tidak melakukan operasi dan mempertahankan penis sebagai alat kelaminnya.

Genderqueer adalah penengah antara cisgender dan transgender yang tidak mengidentifikasi diri berdasarkan gender konvensional (maskulin \& feminin).

Non-binary tidak mengidentifikasikan gender atau seksual berdasarkan dua istilah tradisional yang berlawanan seperti jantan dan betina, hetero dan homo, atau maskulin dan feminin. Namun non-binary mengidetifikasi bahwa gender dan seksual lebih dari dua istilah.

Genderfluid mengidentifikasi diri sebagai orang yang tidak memiliki gender secara pasti karena gendernya bisa berubah seiring berjalannya waktu dan dalam situasi tertentu.

Agender mengidentifikasi diri sebagai orang yang tidak memiliki gender dan tidak mengakui adanya maskulin dan feminin sebagai gender.

Neutrois atau netral, seorang neutrois tidak memihak pada gender atau seksualitas apa pun.

Bigender mengidentifikasi diri memiliki kedua gender (maskulin dan feminin) yang seimbang.

Third gender mengidentifikasi diri memiliki satu atau lebih peran gender lain di luar maskulin dan feminin. Seperti hijra di India. Dokumen legal seperti paspor tidak hanya memiliki pilihan F (female) dan M (male), tetapi juga dengan $\mathrm{O}$ (other).

Gender questioning adalah keadaan seseorang yang masih mempertanyakan identifikasi gender atau seksualitas diri sendiri.

Queer adalah orientasi seksual atau identitas gender lain yang tidak sesuai dengan norma hetero (heteronormatif). Sedangkan kata gay tidak hanya berarti hubungan antara laki-laki sesama jenis namun juga hubungan lain selain hubungan hetero. Seorang lesbian pun dapat menyebut dirinya sebagai gay. Seorang aseksual bisa memilih menyebut diri sendiri sebagai gay atau masuk dalam istilah umum (umbrella term) queer karena secara teknis, aseksual ada di luar heteronormatif.

Sherlock menyebutkan nama lengkapnya, yaitu William Sherlock Scott Holmes sebagai ide jika John mencari nama untuk calon bayinya. Namun John menolak karena calon bayinya adalah perempuan (penanda). Sedangkan William, Sherlock, dan Scott adalah nama untuk laki-laki, apalagi William dan Scott adalah nama yang umum untuk orang Inggris (petanda). Ketika sedang membicarakan Sherlock pun, orang lain juga menggunakan kata 'dia' untuk laki-laki (he) sebagai kata ganti orang ketiga dalam bahasa Inggris (third-person pronoun), bukan kata 'dia' untuk perempuan (she). Ini menujukkan kalau Sherlcok adalah seorang cisgender. 
6. Mendukung praktik hubungan seksual orang lain (walaupun berbeda dengan praktik yang dilakukan diri sendiri)

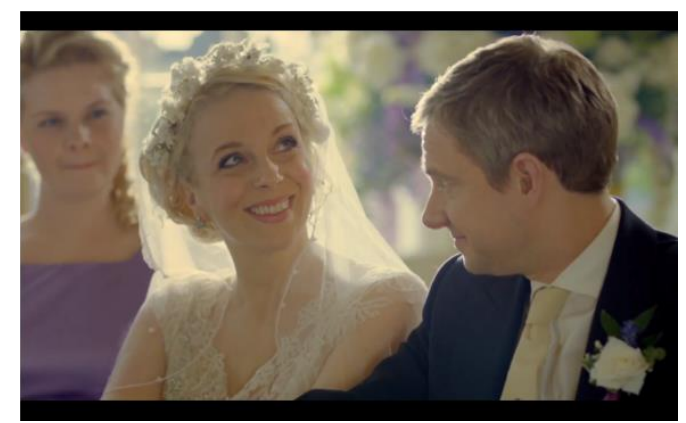

Gambar 3 Mary dan John mendengarkan pidato Sherlock

Sherlock menyatakan bahwa dirinya adalah "orang yang paling tidak menyenangkan, kasar, bodoh, dan bajingan menjijikkan yang menyebabkan rasa tidak beruntung bagi orang lain". Oleh karena itu ia tidak pernah mengharapkan persahabatan dari siapa pun, apalagi dari orang sebaik John. Ia juga menyatakan "Kau pantas menerima pria ini" adalah pujian paling tinggi yang bisa ia berikan untuk Mary, serta John hari ini duduk di antara wanita yang ia jadikan istri dan pria yang dia selamatkan (penanda). Dengan pidato tersebut, Sherlock menunjukkan bahwa ia menyayangi John dan juga menganggap John sebagai sahabatnya (petanda). Sherlock juga mendukung pernikahan John dengan Mary dan ia tidak menunjukkan tanda-tanda seseorang yang merelakan gebetannya (crush) menikahi orang lain. Dalam ciri ini, Sherlcok memenuhi kriteria sebagai orang yang memiliki orientasi aseksual.

\section{Tidak memiliki libido}

Seseorang dikatakan aseksual karena tidak tertarik secara seksual terhadap orang lain, namun tidak berarti tubuhnya tidak mampu mengalami respon. Contohnya puting payudara seorang wanita atau pria bisa menegang jika sedang kedinginan. Libido atau gairah seksual (sex drive) adalah keinginan melakukan hubungan seksual.

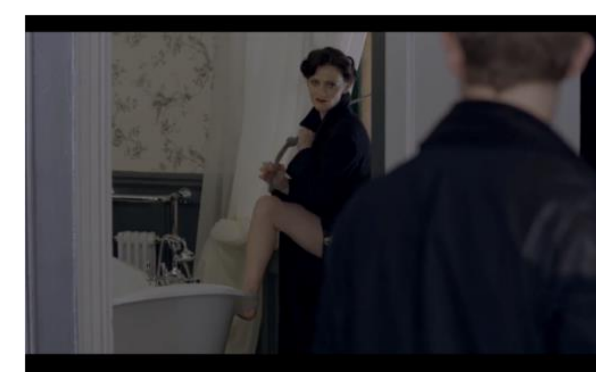

Gambar 4 Irene kabur lewat jendela rumahnya

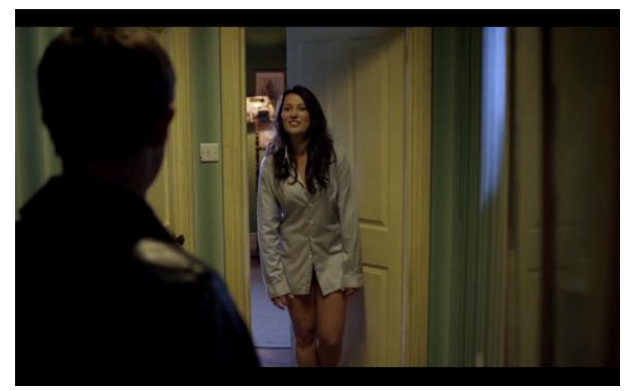

Gambar 5 Janine keluar dari kamar Sherlock

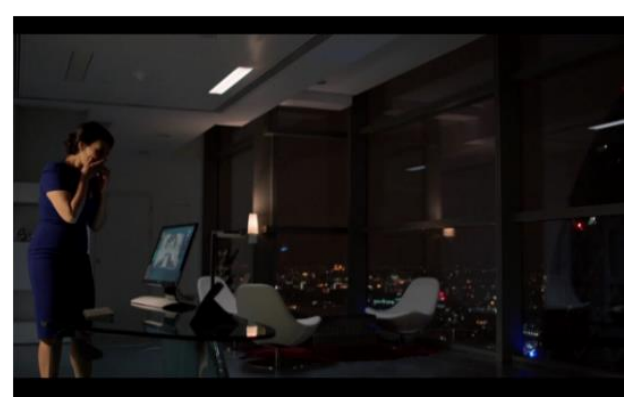

Gambar 6 Sherlock melamar Janine

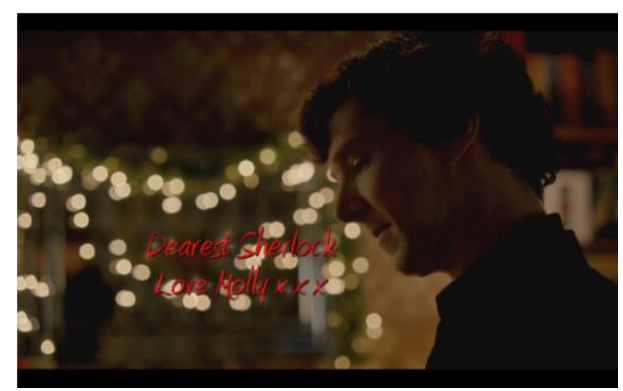

Gambar 7 Sherlock membaca kartu ucapan Molly 
Pada gambar 4, Irene akan kabur setelah menginjeksi Sherlock dengan racun. Ia mengatakan bahwa Sherlock memang memandangi tubuhnya yang tanpa busana. Sherlock berhasil membuka kata sandi brankas Irene yang di dalamnya terdapat telepon genggam berisi foto-foto bersama wanita anggota kerajaan Inggris. Kata sandi tersebut adalah 322434 yang merupakan nomor ukuran tubuh (body measurement) Irene yaitu dada 22, pinggang 24, dan pinggul 24. Angka tersebut didapatkan Sherlock dengan mengukur tubuh Irene hanya dengan memandanginya (penanda). Sherlock tidak menjadikan Irene sebagai obyek seksualnya, namun hanya karena ingin mendapatkan kata sandi brankas (petanda).

Pada gambar 5, Sherlock mengatakan Molly sedang menjalin hubungan serius dengan pacar baru. Hal tersebut berdasarkan deduksi dari beberapa hal, yaitu: kado berbeda yang dibungkus rapi dengan pita merah sewarna dengan gincu yang dipakai Molly; riasan dan gaun yang menunjukkan penampilan fisik Molly berbeda dari penampilannya sehari-hari; serta ukuran bibir dan dada Molly yang membesar. Setelah Sherlock membuka kartu ucapan di atas kado tersebut, ternyata kartu bertuliskan 'Dearest Sherlock, Love Molly $x x x$ '. Molly menulis kata 'salam cinta dari Molly' (Love Molly) dan 'cium cium cium' $\left(\begin{array}{lll}x & x & x\end{array}\right)$ dalam kartu ucapan untuk Sherlock menunjukkan bahwa ia mencintai Sherlock. Kemudian bentuk bibir dan dada yang membesar menunjukkan bahwa Molly ingin menarik perhatian Sherlock secara seksual (heteroseksualitas). Ia ingin Sherlock menjadikannya sebagai obyek seksual. Namun deduksi Sherlock tentang 'Molly memiliki pacar baru' menunjukkan Sherlock tidak menyadari bahwa tindakan Molly ditujukan untuknya (penanda) dan Sherlock tidak menjadikan Molly sebagai obyek seksual (petanda).

Pada gambar 6, Janine menjadi wanita pertama yang berpacaran (in relationship) dengan Sherlock. Janine memasuki kamar mandi saat Sherlock masih ada di dalam. Hal tersebut menunjukkan bahwa Janine dan Sherlock mandi bersama. Pada gambar 7, terungkap alasan Sherlock berpacaran dan melakukan hubungan seksual (mandi bersama) dengan Janine. Dalam komunikasi non verbal, kegiatan mandi bersama menjadi kegiatan seksual karena saat mandi tidak mengenakan pakaian, zona spasial dalam interaksi sosial yaitu zona intim, dan ada sentuhan/heptika (heptics) yaitu rangsangan seksual. Sherlock memacari Janine untuk bisa mendapatkan informasi tentang musuh barunya, Charles Augustus Magnussen, karena Janine adalah asisten pribadi Magnussen. Kemudian Sherlock melamar Janine lewat kamera di depan lift pribadi Magnussen agar Janine bisa membukakan akses lift ke kantor Magnussen (penanda). Melakukan hubungan pacaran serta mandi bersama merupakan bagian dari tipuan Sherlock untuk memanfaatkan Janine (petanda). Hubungan tersebut bukan didasari oleh libido yang ada dalam diri Sherlock, tapi lebih sebagai tipuan. Adegan-adegan tersebut menjelaskan kalau Sherlock adalah orang yang aseksual.

\section{Menarik secara fisik}

Seorang aseksual tidak menjadi aseksual hanya karena ia tidak menarik secara fisik sehingga semua manusia tidak menyukainya. Ketertarikan secara fisik bersifat subyektif.

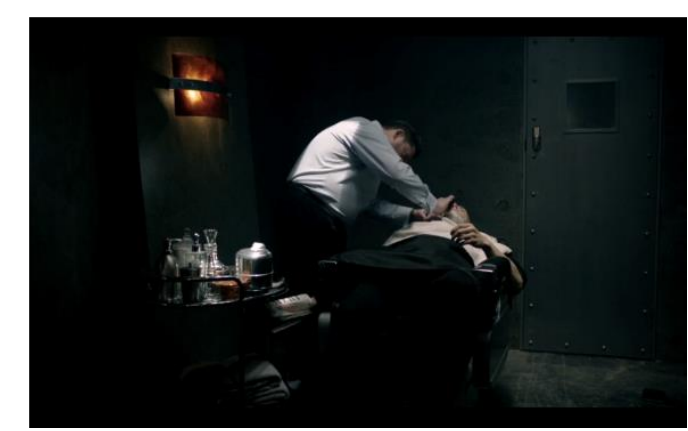

Gambar 8 Sherlock bercukur dalam kantor Mycroft

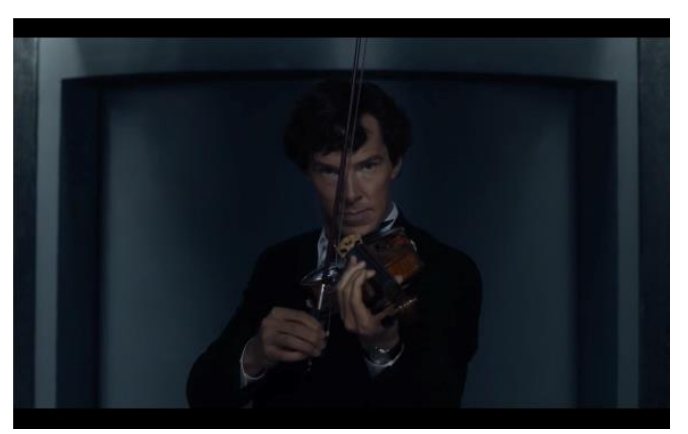

Gambar 9 Sherlock mengenakan sleeves, trousers, suit jacket, dan jam 
Ada sebuah istilah yang disebut sebagai British gentleman, yaitu pria-pria berkebangsaan Inggris yang memiliki ciri ksatria, sopan santun, dan kehormatan. Gentleman juga bisa didefinisikan sebagai pria yang memiliki posisi sosial yang baik, terutama kekayaan dan hiburan yang berkelas. Dalam website majalah mode khusus pria di Inggris yaitu GQ (sebelumnya bernama Gentlemen's Quarterly), ada tiga bagan topik yaitu fashion, watches, dan grooming. Untuk terlihat menarik sebagai British gentleman, ada beberapa hal yang harus diperhatikan seorang pria Inggris yaitu fashion (baju, jam, sepatu, syal, suspender dll), grooming (rambut dan facial hair), dan perkataan (bahasa yang digunakan merupakan bahasa yang sangat sopan dan biasanya hanya dimengerti oleh orang yang mendapatkan pendidikan tinggi). Berikut adalah penanda Sherlock sebagai British gentleman (petanda).

Gambar 8, setelah kembali dari Serbia, Sherlock merapikan diri sekembali ke London. Ia tidak mencukur rambut dan janggut (hair grooming) sendiri, melainkan dilakukan oleh seorang tukung cukur (barber) khusus yang dipanggil ke kantor Mycroft (penanda). Padahal Mycroft adalah orang penting dalam pemerintahan Britania Raya dan tidak mudah untuk memasuki gedung tersebut.

Gambar 9, saat pertama kali bertemu Eurus, Sherlock mengenakan sleeves (kemeja berlengan), trousers (celana kain), suit jacket (jas), sepatu oxford (sepatu formal berbahan kulit), dan jam tangan. Padahal ia baru saja naik kapal, lalu menyamar sebagai petugas keamanan Sherrinford. Ia berganti baju di dalam lift dan setelah berganti baju, tidak ada perbedaan antara kerapiannya tersebut dengan kerapihan saat Sherlock berganti baju di flat (penanda).

Sherlock pernah mengatakan pada Mrs. Hudson, "You're formulating a question and it's physically painful watching you think" dan "I was road-tasting". Ia berbicara dengan menggunakan kata-kata berkelas yang jarang digunakan seperti 'formulating' sebagai pengganti 'making' dan 'road-testing' sebagai pengganti 'practicing'. Jika Sherlock bukan British gentleman, ia bisa mengganti kalimat tersebut seperti “You're making a question and it makes me sick" (penanda). Adegan dan dialog yang tergambar menandakan bahwa Sherlock adalah seorang aseksual.

\section{Tidak tertarik pada hubungan romantis (atau terkadang tertarik dengan hubungan hetero)}

Seorang aseksual bisa memiliki hubungan percintaan dengan orang lain, karena orientasi seksual dan orientasi romantis merupakan hal yang berbeda. Ciri-ciri Decker ini sedikit kontras dengan pernyataan Bogaert (2015) bahwa seorang aseksual bisa menjadi mencintai orang lain dengan jenis kelamin atau gender apa pun, tidak harus heteroromantis.

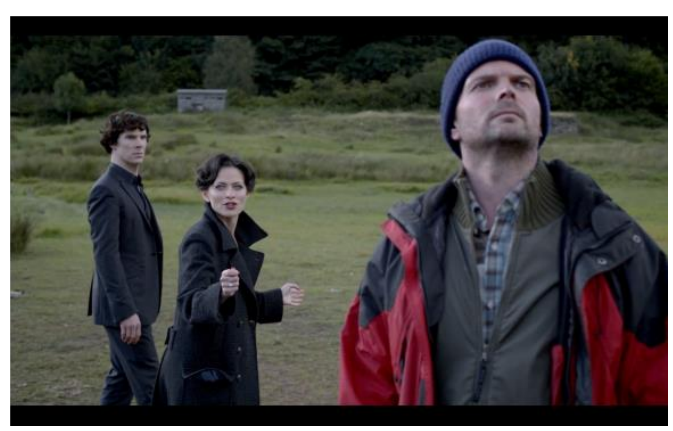

Gambar 10 Sherlock berfantasi Irene berhasil memecahkan kasusnya

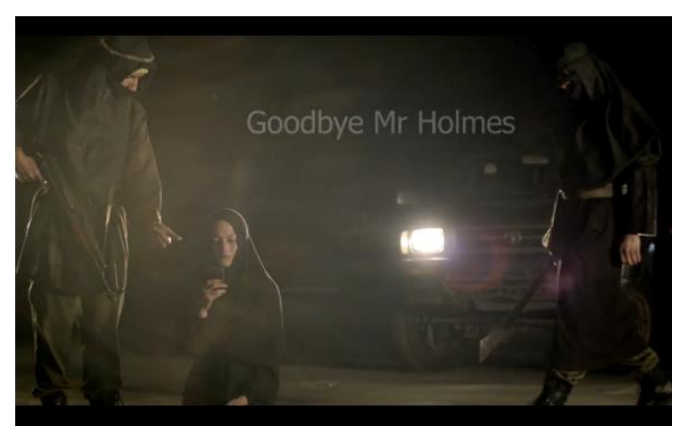

Gambar 11 Irene mengirim SMS untuk Sherlock sebelum eksekusi

Berikut adalah penanda Sherlock sebagai heteroromantis yang mencintai Irene (petanda).

Gambar 10, setelah Irene menginjeksi racun pada tubuh Sherlock hingga ia mengalami kejang-kejang yang menyebabkan halusinasi. Sherlock mengalami setengah-berkhayal-setengah-bermimpi tentang Irene. Sebelumnya Irene pernah mengatakan "I like detective stories. And detectives. Brainy's the new sexy" (S02E01, 00.26.44-00.26.49) saat Sherlock sedang menceritakan kasus sebelumnya tentang seorang pria yang 
meninggal di pinggir sungai. Dalam khayalan dan mimpi Sherlock, Irene berhasil memecahkan kasus tersebut. Irene menyatakan bahwa Sherlock 'seksi' karena berhasil memecahkan kasus tersebut hanya dengan sekali melihat. Namun Irene tidak benar-benar pernah memecahkan kasus tersebut ataupun mengatakan bahwa Sherlock 'seksi', itu hanya terjadi dalam fantasi Sherlock. Khayalan dan mimpi ini menunjukkan bahwa Sherlock ingin Irene tertarik padanya dan melihatnya sebagai pria yang 'seksi' karena kepintarannya (brainy) (penanda).

Ketika Irene meninggal, Sherlock tidak hanya mengalami kesedihan namun nestapa. Kenestapaan Sherlock ditunjukkan melalui sebuah lagu berjudul Irene's Theme yang ia ciptakan menggunakan biola. Dalam episode A Scandal in Belgravia, Sherlock tidak pernah menyatakan bahwa judul lagu tersebut adalah Irene's Theme. Namun dalam album soundtrack Series 2, lagu tersebut berjudul Irene's Theme. Ia juga tidak menyentuh makanannya, yang menunjukkan bahwa meninggalnya Irene menyebabkan ia kehilangan nafsu makan (penanda). Menurut artikel Why Heartbreak Affect Our Appetite oleh Marina Pearson dan Debra Smouse (2013), patah hati dapat penurunan nafsu makan. Pearson dan Smouse menyatakan bahwa tubuh dan pikiran terkoneksi. Ketika seseorang mengalami stres, tubuh akan memproduksi hormon epinephrine (adrenalin; hormon yang meningkatkan denyut jantung dan pelebaran pupil) lebih banyak yang menyebabkan meningkatkan level cortisol (hormon yang meningkatkan gula darah; gula darah pada cortisol berguna untuk sistem imun dan metabolisme). Terlalu tingginya level cortisol dapat menyebabkan menurunnya respons imun, tekanan darah tinggi, dan hilangnya fungsi kognitif (aktivitas berpikir). Hal tersebut mempengaruhi sistem kekebalan tubuh dan sebagian sistem kekebalan tubuh ada di dalam usus, yang juga merupakan sistem pencernaan. Hilangnya nafsu makan Sherlock menunjukkan adanya patah hati (heartbroken) akibat meninggalnya Irene. Hal tersebut dipertegas dengan pernyataan John yang mengira ia akan bertemu Mycroft, ternyata ia bertemu Irene yang memalsukan kematiannya, “He's writing sad music. Doesn't eat, barely talks, only to correct the television. I'd say he was heartbroken but, uh, well, he's Sherlock. He does all that anyway..." (S02E01, 00.52.57-00.53.18).

Gambar 11, Sherlock juga mencintai Irene. Pertama, Sherlock masih menyimpan semua SMS dari Irene di telepon genggamnya. Kedua, Sherlock menyelamatkan Irene yang akan dieksekusi mati di Kariachi, Pakistan. London dan Karachi berjarak $6.340 \mathrm{~km}$ dan penerbangan tercepat memerlukan 11 jam perjalanan. Tidak mudah masuk ke Karachi karena Karachi memiliki penjara bernama Central Prison Karachi, tempat banyak teroris berbahaya dari seluruh dunia dihukum. Untuk bisa memasuki Karachi, Sherlock memerlukan usaha (effort), seperti memiliki jaringan (network/link) 'orang dalam' untuk mengetahui dengan pasti tanggal, jam, dan lokasi Irene akan dieksekusi mati. Ketiga, sesaat sebelum Irene dieksekusi mati, ia mengirimkan SMS terakhir kepada Sherlock dan telepon genggam Sherlock berdering suara desahan Irene. Sherlock tidak mengganti nada deringnya. Keempat, setelah selesai mengingat kejadian penyelamatan Irene, Sherlock menyimpan telepon genggam Irene di laci meja kerjanya (penanda).

\section{Berumur di antara dua puluh hingga empat puluh tahun}

Ketika berumur di bawah 20 tahun, seseorang dianggap belum memiliki ketertarikan seksual karena sistem reproduksi belum bekerja sepenuhnya. Namun perlu diingat bahwa jika seseorang akhirnya mengidentifikasi diri sebagai aseksual, biasanya tanda-tanda sudah ada sejak umur yang masih muda. Bisa terjadi beberapa faktor kesehatan yang mampu mengurangi libido jika seseorang berumur di atas empat puluh tahun.

Drama televisi Sherlock tidak pernah menyatakan usia Sherlock, namun usia Sherlock dapat diperkirakan dengan perbandingan antara drama televisi Sherlock dan canon Sherlock Holmes. Episode The Reichenbach Fall (S02E03) disiarkan pada tahun 2012 dan episode The Empty Hearse (S03E01) disiarkan pada tahun 2014. John marah karena Sherlock memalsukan kematiannya selama dua tahun. Hal ini membuktikan bahwa timeline dalam drama televisi Sherlock mengikuti timeline pada realitas audiens Sherlock. Canon His Last Bow dikisahkan dalam set Agustus 1914 dan saat itu Sherlock Holmes berumur 60 tahun. Dapat diperkirakan Sherlock Holmes lahir di tahun 1854. Sherlock Holmes menghabiskan enam tahun setelah 
lulus kuliah sebagai konsultan sebelum bertemu John Watson pada 1881. Jika dijumlahkan, Sherlock Holmes pertama kali bertemu John Watson pada usia 27 tahun. Jika episode A Study in Pink (S01E01), episode pertama yang mempertemukan Sherlock dan John, disiarkan tahun 2010 dan episode The Final Problem (S04E03) disiarkan tahun 2017, dapat diperkirakan Sherlock dalam Sherlock lahir di tahun 1983 dan berusia 34 tahun di tahun 2017.

\section{KESIMPULAN}

Penelitian menghasilkan beberapa penemuan sebagai berikut. Pertama, John adalah seorang heteroseksual dan heteroromantis, serta hubungannya dengan Sherlock adalah persahabatan (platonic love). Kedua, Molly adalah seorang heteroseksual dan heteroromantis, serta mencintai Sherlock. Ketiga, Irene adalah seorang biseksual dan heteroromantis, serta mencintai Sherlock. Belum ditemukan bukti bahwa Irene pernah mencintai wanita (Irene bukan seorang homoromantis). Keempat, Janine adalah seorang heteroseksual dan heteroromantis. Sherlock secara sadar mengetahui bahwa Molly, Irene, dan Janine mencintainya.

Kesimpulan dari penelitian ini yaitu Sherlock adalah seorang aseksual karena Sherlock memenuhi 8 dari 10 ciri-ciri aseksual menurut Decker (2015). Dua ciri aseksual yang tidak ditemukan dalam Sherlcok sebagai aseksual adalah sehat secara fisik dan mental, serta ekstrover dan/atau berkompetensi sosial. Sherlock terbukti tidak sehat secara fisik dan mental karena menggunkan plester nicotine (nicotine patch) sebagai pengganti rokok. Selain itu Sherlock juga pernah menggunakan narkoba, walaupun bukan dikonsumsi untuk dirinya, namun untuk menjebak musuhnya, Charles Augustus Magnussen dan Culverton Smith.

Sherlock juga mampu dikatakan sebagai seorang heteroromatis terhadap Irene. Sherlock bukan homoseksual dan bukan homoromantis. Jika Sherlock adalah homoseksual dan/atau homoromantis, ada dua kemungkinan yang seharusnya terjadi. Kemungkinan pertama, jika Sherlock seorang homoseksual dan/atau homoromantis yang tertarik pada John, ia sudah melakukan usaha (effort) untuk mendekati John, yang dipermudah dengan mereka tinggal di flat yang sama. Kemungkinan kedua, jika Sherlock seorang homoseksual dan/atau homoromantis tetapi tidak tertarik pada John, ia tidak akan tinggal dalam flat yang sama dengan John karena akan menyulitkannya memiliki hubungan seksual dan/atau hubungan romantis dengan pria lain.

Penelitian ini tidak menemukan bukti bahwa Sherlock adalah seorang heteroseksual, homoseksual, atau biseksual karena dia tidak tertarik dengan hubungan seksual dengan siapa pun. Memang Sherlock terlihat sangat dekat dengan John dan karakter-karakter lain dalam Sherlock sering berpikir bahwa mereka adalah pasangan, namun hal tersebut adalah bagian dari lelucon homoseksual yang dibuat oleh Gatiss yang memasukkan referensi film A Private Life of Sherlock Holmes. Dalam film A Private Life of Sherlock Holmes, Holmes berpura-pura berpacaran dengan Watson untuk menghindari permintaan melakukan hubungan seksual dari Madam Petrova. Dalam Sherlock, hubungan Sherlock dan John adalah persahabatan (platonic love) dan bukan homoromantis.

Sherlock Holmes merupakan karakter fiksi, bukan manusia nyata. Oleh karena itu, tidak dapat dipastikan jika Sherlock Holmes benar-benar aseksual atau dibuat berdasarkan nilai-nilai yang dimiliki Arthur Conan Doyle. Sebelum kematiannya di tahun 1930 pun, Doyle tidak pernah memberikan pernyataan seputar seksualitas Sherlock Holmes. Sherlock Holmes dalam Sherlock pun mendapat beberapa perubahan karakter, namun tanpa mengubah esensi karya asli Doyle.

Orientasi seksual Sherlock Holmes dalam Sherlock dapat diteliti berdasarkan caranya berkomunikasi dan hubungannya dengan orang-orang terdekat dalam penggalan-penggalan scene. Namun penelitian ini dapat berguna bagi masyarakat untuk memahami aseksualitas melalui contoh dalam media yang mudah dikonsumsi.

\section{Daftar Pustaka \\ Buku}

Bogaert, A. F. (2004). Understanding Asexuality. Maryland: Rowman \& Littlefield Publishers. 
Bogaert, A. F. (2015). Asexuality: Prevalence and Associated Factors in a National Probability Sample. The Journal of Sex Research, 41(3), 279-287. (Online). Diakses Jumat, 16 Desember 2016 dari https://www.researchgate.net/publication/8220138 Asexuality Prevalence and Associated Factors in a National Probability Sample.

Bogaert, A. F. (2015). Asexuality: What It Is and Why It Matters. The Journal of Sex Research, 52(4), 362379. (Online). Diakses Jumat, $16 \quad$ Desember 2016 dari https://www.researchgate.net/publication/275278342_Asexuality_What_It_Is_and_Why_It_Matters.

Decker, J. S. (2015). The Invisible Orientation: An Introduction to Asexuality. New York: Skyhorse Publishing.

Pearson, M., Smouse, D. (2013). Why Heartbreak Affect Our Appetite. (Online). Diakses

Selasa, 7 Maret 2017 dari http://www.huffingtonpost.com/2013/10/21/heartbreak-appetiten_ 4098994.html

Purwasito, A. (2007). Analisis Semiologi Sebagai Tafsiran Pesan. Jurnal Komunikasi Massa, 1(1), 65-81.
(Online).
Diakses
Sabtu,
25
Februari
2017
dari

https://digilib.uns.ac.id/dokumen/download/10739/MjQxNDg=/Analisis-Semiologi-Komunikasi-

Sebagai-Tafsir-Pesan-abstrak.pdf.

Sobur, A. ( 2009). Analisis Teks Media. Bandung: PT. Remaja Rosdakarya.

Tribe, S. (2014). Sherlock: Chronicles. London: BBC Books.

Vera, N. (2015). Semiotika dalam Riset Komunikasi. (2 ${ }^{\text {nd }}$ edition). Bogor: Ghalia Indonesia.

Pearson, M., Smouse, D. (2013). Why Heartbreak Affect Our Appetite. (Online). Diakses Selasa, 7 Maret 2017 dari http://www.huffingtonpost.com/2013/10/21/heartbreak-appetite-_n_4098994.html. 